Janusz Cabaj

\title{
FEMINIST LEGAL THEORY: OUTLINE OF THE ISSUE
}

In theory and philosophy of law, or as one can say, in jurisprudence, the dispute about the nature of the law has existed for ages. Traditionally, the axis of the dispute was denoted by advocates of natural law and legal positivism. Simplifying this debate, they have a different answer to the basic question. Whether the law consists of a set of universal moral principles or is it simply a set of rules, orders or norms which are, for the most part, the artifact. This is a normative view of the law, both in the first case and in the second. Moreover, this is a view of the law that is, in principle, neutral, objective, and just. We can say that the law talks with too much pride about itself and that under the rule of law, the liberal ideal of equality is reassured.

Such a vision of the law nowadays is not commonly accepted and without criticism. The law is often depicted as uncertain, ambiguous, and unstable. As many critical theorists assert, the law reproduces economic and political power. Consequently, the law is far from being neutral, determinate or objective. ${ }^{1}$ These critical remarks can be justified in different ways, but a significant component of the critical assault on law is the myth of its determination. As Deborah Rhode points out: "This theoretical approach partly overlaps, and frequently draws upon other critical approaches... At the most general level, these traditions share a common goal: to challenge existing distribution of power." ${ }^{2}$

The analysis of the arguments above isolates the positions more precise. It can be labeled as 'a strand' or as 'a school'.

The first critical approach is Critical Legal Studies (CLS). CLS is often characterized as a subsequent version of the American realist movement of the $1920 \mathrm{~s}$

R. Wacks, Philosophy of Law, Oxford University Press, 2006 , pp. 92-93.

D. Rhode, Feminist Critical Theories, (1990) 42 Stannford Law Review, p. 617 (Wacks, 366). Deborah L. Rhode - professor of law at Stanford University Law School; key works: Speaking of Sex: The Denial of Gender Inequality, Cambridge, MA: Harvard University Press, 1997; (with D. Luban), Legal Ethics, New York, NY: Foundation Press, 4th ed., 2004; Access to Justice, New York, NY: Oxford University Press, 2004; Pro Bono in Principle and Practice, Stanford, CA: Stanford University Press, 2005; (with G.C. Hazard, Jr.), Professional Responsibility and Regulation, New York: Foundation Press, 2nd ed., 2006; Moral Leadership: The Theory and Practice of Power, Judgment, and Policy, San Francisco, CA: Jossey-Bass, 2006; (with C. T. Bartllet), Gender and Law: Theory, Doctrine, Commentary, New York: Aspen Publishers, 4th ed. , 2006; (with B. Kellerman, eds), Women and Leadership: The State of Play and Strategies for Change, San Francisco, CA: Jossey-Bass, 2007. 
and 1930s. However the differences are very essential. Above all, American realism was interested in empirical questions, especially those that attempt to discern the sociological and psychological factors that influence judicial decision-making. The representatives of realism adopted, in principle, the neutrality of law and liberalism ideology. The agents of CLS rejected both. The movement, inspired by Marxism and by psychoanalytical ideas of Freud, in David Trubeck's estimation: (1) contradicts, that law is a "system", and as a body of "doctrine", properly interpreted, provides the answer to all question about social behaviour (principle of indeterminancy); (2) rejects the view that there is an autonomous and neutral mode of legal reasoning (principle of anti-formalism); (3) challenges the idea that doctrine encapsulates a single, coherent view of human reflection - instead, CLS argues that the doctrine represents several different, often competing views, none of which is sufficiently clear and easy to understand to be called dominant (principle of contradiction); (4) rejects the view that law can be regarded as a factor in social behaviour - the factor, which has the ability to make the decision clearly, quickly or finally (decisive factor) (principle of marginality). ${ }^{3}$

The next critical strand is postmodernist legal theory. It reveals a disillusioning bureaucratic suffocation of individuals, the overarching presence of the state, and the increasing globalization of the markets and universalizing of values. ${ }^{4}$ Postmodernists reject "grand narrative". We point out the view of Jean-Francois Lyotard: "I define 'postmodern' as incredulity towards meta-narratives". According to postmodernists, knowledge becomes power in oppressive sense. It comes from the presumption that there is no objective knowledge. There are only claims of truth legitimated by conventions or by some authority. They determine the criteria and the modes of reasoning by which truth is established. ${ }^{6}$ Truth and justice delivered as it were by the meta-systems of Kant, Hegel or Marx are a fantasy for postmodernists. The postmodern appeals are supported on semiotics psychoanalysis of Jacques Lecan. $\mathrm{He}$ argues that unconscious is structured like a language. Structure of language is predetermined by our desires and thoughts, and then we do not control what we say. ${ }^{7}$ Lecan, on the other hand, refers to Freudian conception such as divided human subject: ego, superego and the unconscious and Saussure or Lévi-Straus. The controversial French philosopher - Jacgues Derrida - associates the conception of deconstruction. In some areas, Derrida refers to the views of the German philosopher - Martin Heidegger. ${ }^{8}$ Postmodernist legal theory finds many sympathizers in Poland. However if we accept that the language of law is unavoidably normative, if we 
accept that the legitimacy of the law lies in some conception of justice, it is difficult to explain how the views of Derrida or Lecan can support our understanding of law. ${ }^{9}$

Another challenge to traditional conceptions of law is the Critical Race Theory. It uncovers the nature of law by pointing out that it reflects the interests of privileged, elitist, male and white minorities. The emphasis here is on the racial or ethnic aspects. In CRT's opinion, the racial minority (indeed it is sometimes majority) is pushed out to the margin of legal existence.

And finally - the Feminist Legal Theory. The first political philosopher who distinguished the problem of the equality of men and women was John Stewart Mill. As Mill pointed out: "...the principle which regulates the existing social relations between the two sexes - the legal subordination of one sex to the other - is wrong itself, and now one of the chief hindrances to human improvement; and (...) it ought to be replaced by a principle of perfect equality, admitting no power on the one side, nor disability on the other."'10

Early opposition to the subordination of women was nearly eighty years before Mill in Mary Woolstonecraft's "A Vindication of the Rights of Women" (1792). And even when we read: "...Let women share the rights and she will emulate the virtues of men; for she must grow more perfect when emancipated"11, it does not mean that this entitled women to exercise full political rights.

However, the first book that presented the position of women through the ages was 'The Second Sex' by Simone de Beauvoir. The title of this book formulates a clear message, that "...men defines women not in herself but relative to him; she is not regarded as an autonomous being (...) she is differentiated with reference to man and not with reference to herself; she is incidental, the inessential as opposed to the essential. He is the Subject, he is the Absolute - she is the Other". ${ }^{2}$

There began a process in the United States in the late 1960s. It is called "consciousness raising". This process became the most distinctive aspect of feminist practice. Penner characterizes it in this way: this conception "... was founded on the idea that women were isolated from each other politically, and because of the domination of men over women in any mixed-sex setting, women were often silenced by the conventions of discourse. By allowing women to speak to each other in all-women discussion groups about their own experiences, without their

9 R. Wacks, op. cit., p. 100.

10 J.S. Mill, Subjection of women (1869), Mineolta (NY): Dover Publications, 1997, p. 1.

11 M. Woolstoncraft (1972), A Vindication of the Rights of Women, London: Penguin Classic, 1985 (E. Jackson, N. Lacey, Introducing Feminist Legal Theory [in:] J.E. Penner, D. Schiff, R. Nobles, Introduction to Jurisprudence and Legal Theory: Commentary and Materials, Oxford University Press 2005, p. 782)

12 S. de Beauvoir, The Second Sex, Knopf, 1953, chapter II (J.G. Riddall, Jurisprudence, Oxford University Press, 2005, p. 271). 
speaking being cut short or re-interpreted by men, women's consciousness of their own circumstances would be raised.(...) Individual women would then become capable of analyzing how society oppressed women, identifying occasions where sexist attitudes shaped people's behaviour."13

We can sensibly ask the question: why should we study feminist legal theory? Emily Jackson and Nicola Lacy suitably answer: "At its most basic, feminist legal theory offers a thoroughgoing critique of law's claim to be impartial and objective. While students may have come across this sort of criticism before in particular context where the law has historically treated men and women differently from each other, the claim that the very fabric of the law itself is gendered is both bold and thought-provoking. Studying feminist jurisprudence should equip law students with the theoretical tools necessary to question certain fundamental assumptions about law. (...) students may find that they can identify patterns or trends that both illuminate their understanding of feminist jurisprudence and enrich their studies in other courses." ${ }^{14}$

Certainly, it is not that legal feminists speak with the single voice. ${ }^{15}$ But there is something what unifies all or most of feminists. They refuse any sharp distinction between theory and practice. Some legal questions are not examined to provide theoretical insights. ${ }^{16}$ Far from it they started naming various kinds of behaviour from a feminist perspective. Such terms as "date rape", "domestic violence" or "sexual harassment" put a name to existing and brought them into broader public consciousness. ${ }^{17}$ There is also another thing that unites many feminist theories, its distinctive methodology. Most legal theories adopt either an internal (for example - H. Hart's the concept of law) or an external critique (for example - the CLS movement). Feminist legal theories try to occupy a third perspective: the interpretative one. It means that feminism does not engage in entirely external critiques and prescriptions; it typically does not seek to rationalize legal practices. Feminist jurisprudence aspire to produce an account of legal practices which have a particularly intimate relevance to theory. Any clear-cut separation between theory and practices is rejected. ${ }^{18}$

Therefore, we can distinguish at least three main streams of legal feminism quite a few commentators can find four ${ }^{19}$ or even more. Those streams are connected with some presumptions, but conclusions divide them. As a movement divided into streams, feminist jurisprudence must be distinguished from the much older political

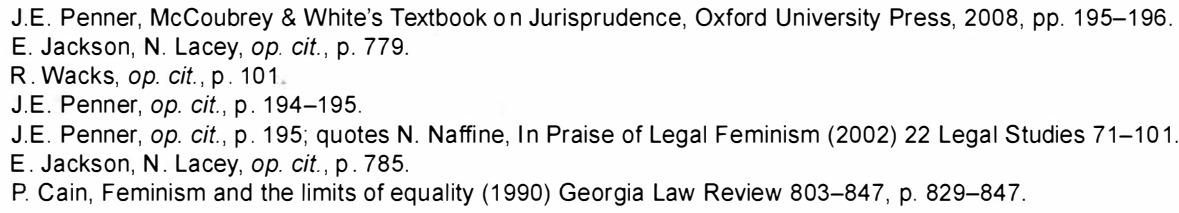


movement for equal rights. The latter struggle began within the framework of the rules of the liberal doctrine. Feminist jurisprudence, on the contrary, finds methods of reasoning and elementary ideas of liberal democracy to be largely responsible for the oppressed condition of women. Therefore, it becomes the third challenge to the liberal legal theory (close to, for instance, CLS or postmodernist jurisprudence), as a kind of radical anti-liberalism. ${ }^{20}$

In order to understand the real nature of law, above all, it should be taken into account its patriarchal character. According to Bix, "...that the law - not just the substantive legal rules, but also the way people reason within and about the law - helps to create or maintain a patriarchal society, one run primarily by and for man, within the intention or effect of subjugating women". ${ }^{21}$ In this structure men have more power than women. Janet Rifkin points out that law is "a paradigm of maleness", that is "the ultimate symbol of masculine authority in patriarchal society". ${ }^{22}$ Thus the law, according to MacKinnon "...not only reflects a society in which men rule women; it rules in male way: "The phallus means everything that sets itself up as a mirror". ${ }^{23}$

Feminist jurisprudence distinguishes typically sex (biological aspects) and gender (cultural or social aspects). We can say that gender is what gives us female and male stereotypes. Thus, examining the social construction of gender allows the theorists to reveal the "hidden" sexism embodied in ideas of what is "natural" to women and men. ${ }^{24}$ But that distinction is not always evident. The most wellknow radical feminist, Catherine MacKinnon"25 explains: "Much has been made of the distinction between sex and gender. Sex is thought the more biological, gender the more social. The relation of each to sexuality varies. Since I believe sexuality is fundamental to gender and fundamentally social, and that biology is its social meaning in the system of sex inequality, which is a social and political system that does not rest independently on biological differences in any respects, the sex/gender

\footnotetext{
20 S. Ratnapala, op. cit., p. 233.

21 B. Bix, A Dictionary of Legal Theory, Oxford University Press, 2004, p. 160

22 J. Rifkin, Toward a Theory of Law and Patriarchy, (1980) 3 Harvard Women's Law Journal, p. 83-84 (Olsen, 461)

23 C. MacKinnon, Feminism, Marxism, Method and the State: Towards Feminist Jurisprudence [in:] A.C. Hutchinson (ed.), Critical Legal Studies, Totowa, New Jersey: Rowman \& Littlefield Publishers, 1989, p. 62. J.E. Penner, op. cit., p. 194

25 Catharine Alice MacKinnon (1946 -) - professor of law at University of Michigan Law School; most important books: Sexual Harassment if Working Woman: A Case of Sex Discrimination, Yale University Press, 1979; Feminism Unmodified: Discourse on Life and Law, Cambridge: Harvard University Press, 1987; (with A. Dworkin), Pornography and Civil Rights: A New Day for Woman's Equality, Organizing Against Pornography, 1988; Toward a Feminist Theory of the State, Cambridge: Harvard University Press, 1989; Only Words, Cambridge: Harvard University Press, 1993; (ed. with A. Dworkin), In Harms Way: The Pornography Civil Rights Hearings, Cambridge: Harvard University Press, 1997; Women's Lives, Men's Laws, Cambridge: Harvard University Press, 2005; Are Women Human? And Other International Dialogues, Cambridge: Harvard University Press, 2006.
} 
distinction looks like a nature/culture distinction. I use sex and gender relatively interchangeably." 26

In literature, the distinction suggested by Frances Olsen is adopted commonly. ${ }^{27}$ Olsen sets out a series of dualisms with features or characteristics connected with masculinity on the left, with their feminine counterparts on the right. ${ }^{28}$

1. Rational - irrational.

2. Active - passive.

3 . Thought - feeling.

4. Reason - emotion.

5. Culture - nature.

6. Power - sensitivity.

7. Objective - subjective.

8. Abstract - contextualized.

9. Principled - personalized. ${ }^{29}$

The system of dualisms has three important characteristics:

1. The dualisms are sexualized. One-half of each dualism is regarded as masculine, the other half as feminine.

2. The terms of the dualism are not equal, but they are considered to constitute a hierarchy. In each pair, the term identified as "masculine" is privileged as superior, while the other is considered negative, spoiled, or inferior.

3. Law is identified with the "male" side of the dualisms. ${ }^{30}$

Awareness of this issue allows us to call some of the discriminatory practices against women not as " sexism", but as "genderism".

C. MacKinnon, Feminism, Marxism, Method and the State: Towards Feminist Jurisprudence [in:] A.C. Hutchinson, Critical Legal Studies, Rowman \& Littlefield Publishers, Inc., 1989, note 1, p. 72.

Frances Elisabeth Olsen - professor of law at University of California School of Law; most important books: (with Walter O. Weyrauch and Stanford N. Katz) Cases and Materials on Family Law: Legal Concepts and Changing Human Relationship, West Publishing, 1994; (ed.), Feminist Legal Theory I: Foundations and Outlooks, Dartmouth Publishing, NYU Press, 1995; (ed.), Feminist Legal Theory II: Positioning Feminist Theory Within the Law, Dartmouth Publishing, NYU Press, 1995; (edited by F. Olsen, Dieter Stein and Alexander Lorz), Law and Language: Theory and Society, Düsseldorf University Press, 2008; (edited by Frances Olsen, D. Stein and A. Lorz), Translation Issues in Language and Law, Palgrave/Macmillan, 2009. Moreover she has written about 100 articles published world-wide, including in the Harvard Law Review and Yale Law Journal. J.E. Penner, op. cit., p. 202.

29 F. Olsen, Feminism and Critical Legal Theory: An American Perspective (1990) 18 International Journal of the Sociology of Law, p. 200

30 F. Olsen, The Sex of Law [in:] D. Kairys (ed), The Politics of Law: Progressive Critique, New York: Pantheon Books, 1990, p. 453. 
Commonly, classical jurisprudence clearly did not overlook the position of women. Somebody can say that jurisprudence is about what law is. In this meaning, the writings of J. Austin, H. Kelsen, H. Hart, L.L. Fuller, R. Dworkin that is jurisprudence. Perhaps feminism should be a part of politics or social history or sociology? ${ }^{31}$ Feminist legal theory supplements this neglect currently. The development of this theory not only was considerable impact on theory itself, but also on the university law curricula, at least in England and the United States. In light of this theory, students can explore rape law and other rules of criminal law (domestic violence), martial law, family law, labor law, as well as contract and tort law. Law as a system can be analysed in relation to some aspects of international law. It can be pointed out that feminist legal theory impacts, perhaps not directly, on the breaking off some deep-rooted common law principles. For example, a husband cannot be prosecuted for raping his wife, despite her refusal to consent to sexual intercourse. Her consent was presumed by the plain fact of marriage. It is not like that nowadays. ${ }^{32}$

Liberal feminism aspires to be called authentic or original..$^{33}$ This version is based on the idea of formal equality and of equality of opportunity. But while liberalism requires laws it is sex-blind. In some degree, it fulfills its tasks but, in principle, in the public sphere. The dichotomy between the public and the private is "ultimately what the feminist movement is about". ${ }^{44}$ In their private relations liberals often do not see the anchored sexism. They have problems showing how patriarchy fails to recognize the economic value of the contribution of women constituted by child rearing and housework. They also do not perceive that formal equality in public life can be an illusion for women. Especially for those who are permanently maltreated by their own husbands in their own places. Liberal feminists point out that a private sphere operates according to a different logic than a public one. In a private sphere - they maintain - it would be something inappropriate for the state or for law to enter a place or situation without permission..$^{35}$ Liberals wrongly adopt that a lack of equality in private relations does not influence on the rights executed in a public sphere. Lacey points out that: "The ideology of the public - private dichotomy allows government to clean its hands of any responsibility for the state of the 'private' world and depoliticises the disadvantages which inevitably spill over the alleged divide by affecting the position of the 'privately' disadvantaged in 'public' world."'36

J.G. Riddall, op. cit., pp. 288-289

R. Wacks, op. cit., p. 101.

But MacKinnon maintains that in fact only radical feminism is truly feminist legal theory; $E$. Jackson, N. Lacey, op. cit., p. 738 
It seems that the issue of private relationship is the arena on which radical feminists criticize liberalism successfully because of its conception of individuals autonomy. Under liberalism, each individual is autonomous and free from constraints (with the freedom of association, freedom from irrational preferences and desires) imposed by others in being the author of his own life. However, many of the followers of feminist legal theory, and from other legal theories, challenge the concept of autonomy in this sense. Social connections, especially ones within the family, are not simply a matter of consumers choice, for example: to buy or not to buy. Those connections are constitutive of a person's identity. But liberalism is blind to this, as well. It does not take into account the way in which sexism might be embedded in our social relationships. ${ }^{37}$

Further, taking into account that each individual is entangled in the net of social relationship, it is difficult to say that an individual is free and, in principle, makes rational choices. Sometimes (perhaps often) he or she is out of choices. Even if individuals act "freely" from social and political influence - from external factors they have over the content of their preference and strong desires. ${ }^{38} \mathrm{~A}$ picture of an individual as essentially a rational chooser was established on a priori conception of the nature of the human being. However, this reasoning is incorrect. It does not matter whether the presumption or the conclusion is wrong. This is particularly important in understanding the legitimacy of the way individuals treat each other. This is not an introduction of Kantian categorical imperatives (the formula of the end-in-itself): "Act in such way that you always treat humanity, whether in your own person or in the person of any others, never simply as a means, but always at the same time as an end". ${ }^{39}$ Critics of liberal feminist jurisprudence point out that women are treated instrumentally too often. Therefore, from a male point of view this is simply a rational behaviour..$^{40}$ Liberal feminists tend to favor the sameness thesis, but they do not want to deny women's differences from men. Formal equality does not mean the sameness. We should respect the differences, discredit the false ones, and perceive the common ground. As Wendy Williams graphically says: "We who are different share in this particular context at this particular time a quality, trait, need or value that locates us on the same platform for this particular purpose; we see a connection in a particular respect that we who are different think entitles us to partake in the same meal, drink at the same trough, or march to the same drummer at least in this particular parade." ${ }^{41}$ 
Radical feminist jurisprudence concentrates mainly on women discrimination with respect to sex, not gender, in anatomical sense. Thus, the core of radical feminists' interests (with MacKinnon as leader) are legal regulations referring to pornography, rape, marital relationship, and right to abortion. The problem of rape recurs again and again through the radical literature. This crime is taken to be as a dark symbol of women's sexuality. But how do women understand the concept of rape? MacKinnon explains: "Perhaps the wrong of rape has proved so difficult to define because the unquestionable starting-point has been the rape is defined as distinct from intercourse, while for women it is difficult to distinguish the two under conditions of male dominance." ${ }^{42}$ Further: "Rape should be defined as sex by compulsion, of which physical force is one form. Lack of consent is redundant and should not be a separate element of the crime." ${ }^{\prime 43}$

Such convictions lead MacKinnon to a more general conclusion. It refers to women's way of thinking about the rape law. According to her: "Rape, from women's point of view, is not prohibited; it is regulated. Even women who know we have been raped do not believe that the legal system will see it the way we do. We are often not wrong. Rather than deterring or avenging rape, the state, in many victims' experiences, perpetuates it. Women who charge rape say they were raped twice, the second time in court. If the state is male, this is more than a figure of speech." ${ }^{\prime 44}$

With reference to pornography, radical feminists are less concerned with morality of any sexually explicit film, picture or text. They are concerned with the way certain forms of such materials sexualizes the subordination of women within the society to silence women's speech..$^{45}$ As MacKinnon points out, women should not be depicted as a sexual object: "The mass production of pornography universalizes the violation of women in it, spreading in to all women, who are then exploited, used and abused, and reduced as a result of men's consumption of it. In societies pervaded by pornography, all women are defined by it: this is what woman wants, this is what a women is." ${ }^{\prime 4}$

MacKinnon treats women as a class, but as Lucinda Finley pointed out, not all women share MacKinnon's views of acceptable sex. ${ }^{47}$ Her view neglects differences among women themselves, and moreover - it gives for the state the censoring power to define what is acceptable sex for women as a class.

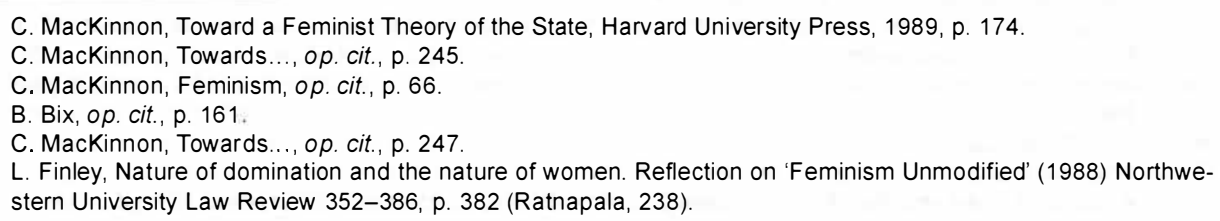


Within the group of radical feminists are also Frances Olsen (some of the commentators recognizeOlsen as a leading postmodern feminist ${ }^{48}$ ), Andrea Dworkin ${ }^{49}$, and Deborah Rhode. According to them, many of the male - female relationship are stigmatized with male domination that has a sexist base. Unfortunately, they ignore the fact that most of women, especially at home, do not feel the ubiquitous male domination. Even then women feel themselves to be exploited, it has much more complex reasons than simply sexism.

As opposition to liberal feminism that is shaped by its upbringing idea of equality, radical feminism is interested in the differences. While liberals see abstract rights, radicals see expression and authorization of male understanding and experiences of the world. While liberals are absorbed in their sophisticated analysis of the concept of rights, radicals simply say: down to earth, let us deal with the facts. Such facts are the domination of women by men. There are many trappings of male domination; only it should be named. The sexual division for radical feminists is as foundational one as for Marxist class divisions, that is to say, as the central organizing feature of economic, social, and political life. ${ }^{50}$ Everything is hidden behind the mask of the liberal neutrality of the law. Neutrality of which understanding was historically defined by men. Neutrality that now reproduces and perpetuates social relationships - by the way - was dominated by men, too. This is a real women's world in which they recognize the patriarchal system which subjugates them. ${ }^{51}$

Therefore, there is no neutrality. Social relationship, as a whole, are determined by men. This domination is based on male power over women and that is understood as some kind of sexual strength. "The injustice of sexism is not irrationality; it is domination. Law must focus on the latter, and that focus cannot be achieved through a formal lens." ${ }^{52}$ Male domination is most evident in the area of sex and reproduction. MacKinnon says this explicitly. She uses consciously some figures of speech. In this case, the domination is obvious and it comes directly from the meaning of words: to be "on top". Such language games allow MacKinnon to maintain that sexism is embedded in our language, in particular, in language which deals with sex. MacKinnon has formulated some well-known claims; we can say it is classic

R. Wacks, Understanding Jurisprudence: An Introduction to Legal Theory, Oxford University Press, 2009, p. 366 .

Andrea Rita Dworkin (1946-2005) - most important books: Woman Hating: A Radical Look at Sexuality, E.P. Dutton, 1974; Our Blood: Prophecies and Discourses on Sexual Politics, Harper \& Row, 1976; Pornography - Men Passing Women, E.P. Dutton, 1981; Right-Wing Women: The Politics of Domesticated Females, The Women's Press, 1983; (with C. MacKinnon), Pornography and Civil Rights: A New Day for Women's Equality, Organizing Against Pornography, 1988; Letters from a War Zone: Writings, Lawrence Hill Books, 1993; (with C. MacKinnon), In Harm's Way: The Pornography Civil Rights Hearings, Cambridge: Harvard University Press 1997; Life and Death; Unapologetic Writings on the Continuing War Against Women, Free Press, 1997; Scapegoat: The Jews, Israel, and Women's Liberation, Free Press, 2002; Heartbreak: The Political Memoir of a Feminist Militant, Basic Books, 2008.

A Scales, The Emergency of Feminist Jurisprudence: En Essay (1986) 95 Yale Journal 1373, p. 1385 
nowadays. Its semantic analysis defines relationships between men and woman. She has said: "Man fucks woman: subject - verb - object". ${ }^{53}$ Something like: peasant - ploughs - field. There is no reciprocal relationship; it can be seen clearly. ${ }^{54}$ The change of classification: subject - object is impossible because of the nature of this activity.

Another reaction for liberal feminism is cultural feminism, also called differences feminism. As its name indicates, this theory emphasizes the importance of and attention to differences between sexes. Cultural theorists claim that there are no individuals in liberal meaning, but - men and women. The motto of different feminism could be: 'Equality does not mean sameness'. ${ }^{55}$ The most evident example of this slogan could be the sameness of the factual status "to have children". It is clear that it does not mean the same from a man's and woman's legal perspective. There is enough to refer to labour law. Thus, if we demand equal protection it does not mean that protection should be identical. Therefore, while we try to determine the meaning of legal norms we should take into account both sex and gender. Works of Robin West ${ }^{56}$, but especially of Carol Gilligan ${ }^{57}$ (In a Different Voice) awaken us that while men go by "ethics of rights", women go by "ethics of care". West's characterization of this strand of feminism can be summed up in her connection thesis. 'The connection thesis is simply this: Women are actually or potentially connected to other human life. Men aren't." 58

Representatives of feminist jurisprudence see in Gilligan's work the hidden critique of a legal system. Court procedure is a principle discouraged to compromise. Competition dominates - as a result, 'winner takes all'. To such games men generally are more likely suited. There are many women in legal profession nowadays. However, men resolve legal conflicts as they resolve social conflicts in daily life - by the law's rules. In this way, the law can be seen to take a masculine

53 C. MacKinnon, Feminism Unmodified: Discourse on Life and Law, Cambridge: Harvard University Press, 1987, p. 124

54 J.E. Penner, op. cit., p. 205.

55 J.E. Penner, op. cit., p. 200.

56 Robin L. West - professor of law at Georgetown University Law Center; the most important books: Narrative, Authority, and Law (Law, Meaning, and Violence), University of Michigan Press, 1993; Progressive Constitutionalism: Reconstructing the Fourteenth Amendment, Duke University Press, 1994; Caring for Justice, New York University Press, 1999; Rights, Ashgate Publishing Co, 2000; Re-Imagining Justice: Progressive Interpretations of Formal Equality, Rights, and the Rule of Law, Ashgate Publishing Co, 2003.

57 Carol Gilligan (1936 - ) - professor of psychology at New York University School of Law; best known books and novels: In a Different Voice, Harvard University Press, 1982; (with J.V. Ward, J.M. Taylor, eds.), Mapping the Moral Domain: A Contribution of Women's Thinking to Psychological Theory of Education, Harvard University Press, 1989; (with N.P. Lyons, T.J. Hanmer, eds.), Making Connections: The Relational Worlds of Adolescent Girls at Emma Willard School, Harvard University Press, 1990; (with L.M. Brown), Meeting at the Crossroads: Women's Psychology and Girls' Development, Harvard University Press, 1992; (with J.M. Taylor, A.M. Sullivan), Between Voice and Silence: Women and Girls, Race and Relationships, Harvard University Press, 1997; The Birth of Pleasure, New York: A. Knopf, 2002; Kyra, New York: Random House, 2008; (with D. Richards), The Deepening Darkness: Patriarchy, Resistance, and Democracy's Future, Cambridge University Press, 2009. 
approach in its very reasoning. It also should be noted (but we do not agree with it necessarily), that female lawyers have a more natural inclination to different ways of moral reasoning..$^{59}$ It means that if woman wants to take upon herself the equivalent struggle against man in court, she must argue as he does. But if she is a judge, another problem can appear. It can be termed as a lack of the male understanding: of the accused, of the party in a civil case, also of their proxies. If we consider this fact, we better understand the reasons of law interpretations made by the female judge. Especially, functional interpretations, which does not refer to such female inclinations directly.

Cultural feminism is the object of critique, as well. This critique comes from various directions. For example, to expose the conception of ethics of care can be a double-edged argument. In such cases, the difference feminism may appear to put women in a particular place, to those traditional roles of the caring professions, baby sitters, nurses, housekeepers, teachers, and of course - motherhood ${ }^{60}$ Therefore liberal feminists cry out: "If you want to have equal rights than behave as a man". Then this proposition could seem very attractive.

On the other hand, we can say that cultural feminism is open to the claim (like radical feminism) that it essentialises women as the connected sex. From a liberal feminists perspective, it can be viewed as politically conservative. "Among critical theorists, the focus of arguments regarding essentialism is usually on the extent to which the sexes (...) could be said to have a basic nature, or a distinct way of thinking, analyzing, or experiencing the world. ${ }^{" 61}$ In wider sense, in feminist writings, "...essentialism is the view that females (or males) have an essential nature (e.g. nurturing and caring v. being aggressive and selfish), as opposed to differing by a variety of accidental or contingent features brought about by social forces. ${ }^{162}$ In this case, essentialism can be understood as a false belief that a category of women has a fixed nature, and this nature is strictly connected to sex. This debate makes sense only if we accept "essentialism" as contrasted with "nominalism".

Liberalism accepts sexuality. It means that liberalism perceives social differences that are constructed on male and female characteristics and that these features are valued in a different manner. Liberals, other than radical feminists, reject conceptions that male characteristics are more valued than female ones, and also that these characteristics make up a hierarchy. ${ }^{63}$

For example, radicals will say that in the hierarchy rationalism takes a higher place than irrationalism, but liberals are untruthful telling that women cannot behave

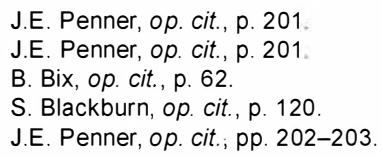


more rational than men. Instead, cultural feminists will agree that, in principle rationalism is a male characteristic but they will not agree that rational behaviour is always more valued than irrational. Moreover, it seems that rationalism is not to be found in a pure form.

Some of the agents of jurisprudence adopt the strands mentioned above in some sense as a models and unite them with other legal critical theories. In accordance with Carol Smart ${ }^{64}$ we can distinguish Marxist Feminism. This theory looks for the analogy between two kinds of exploitation. In the first case, this is a class exploitation. In the second - women are exploited in the process of reproduction. She also argues (but we should be careful about this), that sexual submission is only an epiphenomenon for class submission. According to her, it means that sexual submission is an incidental product of process of class submission that has no effects of its own.

While the example of race discrimination has been invoked already, it should be noted the theory of racial feminism (Colour of Feminism), especially with reference to the status of black women. This issue is analyzed by Patricia Hill Collins, ${ }^{65}$ (Black Feminist Thought: Knowledge, Consciousness and the Politics of Empowerment). She comes to the conclusion that the oppression of black women in the US can only be seen when both race and sex are taken into account. In her analysis, Collins tries to fight against such stereotypes of black women as the "welfare mother", the "Jezebel" (the sexual aggressive women), and the surrogate mother to usually white children ("mammy"). ${ }^{66}$ In the words of Brian Bix, "...critical race theory's focus on the distinctive experiences and perspectives of racial and ethnic minorities, it was perhaps predictable that it would lead to an ever-expending list of categories of scholarship defined more narrowly, in terms of the experiences of particular racial and ethnic groups or sub-groups, such as 'critical latino/a theory' (also known as

Carol Smart - criminologist and sociologist; academic at the University of Manchester. Most important books: Women, Crime, and Criminology: A Feminist Critique, London: Routledge \& K. Paul, 1976; Women, Sexuality, and Social Control, London: Routledge, 1978; The Ties that Bind: Law, marriage and the reproduction of patriarchal relations, London: Routledge \& K. Paul, 1984; (with S. Sevenhuijsen), Child Custody and the Politics of Gender, London: Routledge, 1989; Feminism and the Power of Law, London: Routledge, 1989; Regulating Womanhood: Historical Essays on Marriage, Motherhood and Sexuality, London: Routledge, 1992; Law, Crime, and Sexuality: Essays in Feminism, London: Sage Publications Ltd, 1995; (with B. Neale and A. Wade) The Changing Experience of Childhood: Families and Divorce, Cambridge: Polity Press in association with Blackwell Bublishers, 2001.

65 Patricia Hill Collins (1948 -) - Distinguished Professor of Sociology at the University of Maryland, College Park; the first and best known book is Black Feminist Thought: Knowledge, Consciousness and the Politics of Empowerment, London: Routledge, 1990; and others, most important ones: (with M. Anderson, eds), Race, Class and Gander: An Anthology, Wadsworth Pub. Co., 1992; Fighting Words: Black Women and the Search for Justice, Minneapolis: University of Minnesota Press, 1998; Black Sexual Politics: African, American, Gender, and the New Racism, London: Routledge, 2005; From Black Power to Hip Hop: Racism, Nationalism, and Feminism, Philadelphia: Temple University Press, 2006; Another Kind of Public Education: Race, the Media, Schools, and Democratic Possibilities, Boston: Beacon Press, 2009. 
'LatCrit theory'), 'Chicano/a studies', 'Asian critical theory', and the like (along with combinations such as 'critical race feminism'). ${ }^{67}$

The racial feminism conceptions are, on the one hand, an attempt of reinforcement of feminism, in general, but on the other, an attempt of rejection of the racial critique. Naffine concludes: “...a persons sex may not always be the most fundamental marker of either their oppression or advantage. Sometime race, for example, might assume a greater priority and so a women might feel a greater allegiance with a men of her own race than a women from another." 68

The similar interest can be found in Angela Harris works ${ }^{69}$. She has studied one of the most important objections against feminism, namely - the objection of essentialism. It should be understood, in short, as ignorance of the differences between women themselves, in this case - racial or ethnic ones. ${ }^{70}$

Ignoring of these differences can even bring somebody to anti-racial associations. In the United States feminist movements have organized marches against rapes, socalled "Reclaim the Night". Such marches were often dominated by white women, and its scenery (by candle-lights) calls to mind the fashion of the Ku-Klux-Klan processions. Moreover, we should remember, that in the history of the United States, the rapes that were committed by black men are very complex and a thorny issue. Rape accusations often were finished with lynching, and sometimes the accusations were false, especially when white woman gave birth to a black child. ${ }^{71}$

Feminist Legal Theory share some common ground with Critical Legal Studies. The most important ones are a condemnation of injustice and of skepticism as to the alleged neutrality of the rule of law. Feminists and Critics do not believe that law is separated from politics. What is more, feminists see law and politics as the instrument of male domination but share with Critics that the existing distribution of power should be challenged. On the other hand, CLS presents oppression in the abstract, it does not see the oppressed themselves. CLS' vision of a better society is expressed in idealized and generalized terms. What does Roberto Unger's appeal

\section{B. Bix, op. cit., p. 47}

Ngaire Naffine ( ) - Professor of Law at the University of Adelaida; most important books: Law and the Sexes in Feminist Jurisprudence, Allen \& Unwin, 1990; (ed), Gender, Crime and Feminism, Dartmouth Pub Co, 1995; Feminism and Criminology, Polity Press, 1996; Gender and Justice, Dartmouth Publishing Co Ltd, 2002; Law's Meaning of Life: Philosophy, Religion, Darvin and the Legal Person, Hart Publishing, 2009; N. Naffine, In Praise of Legal Feminism, (2002) 22 Legal Studies 71-101, p. 88 (Wacks, Understanding..., p. 360).

Angela P. Harris - Professor of Law at University of California, Berkeley School of Law; most important books: (with K. Bartlett and D. Rhode), Gender and Law: Theory, Doctrine, Commentary, Aspen Law \& Business, 1998; (with J. Perea, R. Delgado and S. Wildman), Race and Races: Cases and Resources for a Diverse America, West Group, 2000; (with C. Lee), Criminal Law: Cases and Materials, Thompson/West, 2005.

E. Jackson, N. Lacey, op. cit., p. 840.

E. Jackson, N. Lacey, op. cit., p. 840-841. 
to a world free "from deprivation and drudgery" mean? As Rhode says: "Such formulations leave most interesting question unanswered." $" 72$

Other feminist legal theories are united with postmodern vision of law, and bring to life Postmodern Legal Feminism as a response to the perceived failures of liberal, radical, and cultural-differences feminisms. ${ }^{73}$ Postmodernists displace CLS as the major force in radical jurisprudence. They question the liberal claims to objectivity of the law on epistemological grounds. The idea, so central to the liberal thinking, that there is a self-contained "subject" separable from social reality is rejected by postmodernist. In legal theory, postmodernism concentrates on deconstruction and on language game theory. The theory of deconstruction is the most radical form of the postmodernist movement. In short, this theory professes that there is no reality outside of texts. Words gain their meaning in the process of infinite regression, from their difference from other words, and so on. ${ }^{74}$

In the area of postmodern feminism we can find the analyses of Mary Joe Frug 75 . The alliance with postmodernists is not easy. As we know, they are skeptical about appeals to universality. Consequently, feminist theories should show more care in appealing to essentialism. In Frug's words: "in their most vulgar, bootlegged versions, both radical and cultural legal feminisms depict male and female sexual identities as anatomically determined and psychologically predictable. This is inconsistent with the semiotic character of sex differences and the impact that historical specificity has on any individual identity. In postmodern jargon, this treatment of sexual identity is inconsistent with a decentered, polymorphous, contingent understanding of the subject." ${ }^{976}$

To move away from essentialism, Katherine Barlett argues for what she calls "positionality". As she puts it: "...particular involvements and relationship..., not some essential or innate characteristic of the individual, define the individual's perspective and provide the location for meaning, identity, and political commitment". ${ }^{77}$ The truth is seen as situated and partial. Her opinion, however, dangerously approaches to relativism. It states that postmodern feminists must face the charge that their views provide no basis for valid critical scrutiny. If ever perspective is equally valid, then none is. ${ }^{78}$

D. Rhode, Feminist Critical Theories (1990) 42 Stanford Law Review 617-638, p. 617.

J.E. Penner, op. cit., p. 203

S. Ratnapala, op. cit., p. 15

Mary Joe Frug (1941-1991) was a professor at New England School of Law in Boston, Mass. Murdered on the street not far from her home. The most important books: Postmodern Legal Feminism, London: Routledge, 1992; Women and the Law, Foundation Press, 1992; Case Supplement to Women and the Law, Foundation Press, 1995.

M.J. Frug, A Postmodern Feminist Manifesto: An Unfinished Draft (1992) 105 Harvard Law Review 1045, p. 1046.

K.T. Barlett, Feminist Legal Methods (1990) 103 Harvard Law Review 829 [in:] Lloyds..., pp. 1212-1214.

J.E. Penner, op. cit., p. 204 
Postmodernist methods, in particular deconstructive ones, can be useful in the disclosure of racist ideology in Western culture, thus indirectly - it can be useful in the disclosure of implicit anti-feminism. Some commentators ${ }^{79}$ argue, that laws of Western societies are permeated by racism. It relates to the law as a system: its concepts, rules and institutions.

In Cheryl Harris words: "The deeper race-crits dig, the more embodied racism seems to be; the deeper the race-crit critique of Western culture goes, the more useful postmodernist philosophy becomes in demonstrating that nothing should be immune from criticism... Postmodernist critique potentially clears the way for alternative accounts of social reality, including accounts that place racism at the center of Western culture". 80

But the ethics of care argument can be employed to transact an alliance, for example, with ecological movements. The extent of the inherent carefulness of women should be only spread out and should include carefulness to the environment.

The direction of feminist legal theories development is not determined. But one should take into consideration the regeneration of liberal feminism. The philosophy of Martha Nussbaum is testimony of it. ${ }^{81}$ She tries to exploit great strength of liberal traditions, it means, its concern that the purpose for which the State and the law are instituted is to contribute to the flourishing of each individuals - their lives are considered "one by one" and not merely as members of the groups; the individual should not be sacrificed in the interest of others. ${ }^{82}$ For that matter, the position of women should be shown not in the collective perspective but by the prism of each single legally discriminated human beings, in this case - a woman.

Probably, gender will be an important axis of social division. However, we must agree that it will be not only, or even necessarily, the most substantial factor. There are many elements of structural social differentiation. We can indicate, for instance, age, class, disability, and obviously - race. And should not be unsurprising that the factors mentioned above have disposition to overlapping. ${ }^{83}$

R. Chang, Toward an Asian American Legal Scholarship: Critical Race Theory, Poststructuralism, and Narrative Space (1993) 81 California Law Review 1243. See: too on Latino-Critical Studies: R. Delgado and J. Stefanic (eds), The Latino Condition: A Critical Reader, New York: New York University Press, 1998; R. Delgado and J. Stefanic, Critical White Studies: Looking Behind The Mirror, Philadelphia, Penn: Temple University Press, 1997.

80 Ch. Harris, Whiteness as Property (1993) 106 Harvard Law Review 1707.

81 Martha Craven Nussbaum (1947 -) - Distinguished Service Professor of Law and Ethics at the University of Chicago. Most important books: Sex and Social Justice, Oxford University Press, 1999; Women and Human Development: The Capabilities Approach, Cambridge University Press, 2000; Upheavals of Thought: The Intelligence of Emotions, Cambridge University Press, 2001; Hiding From Humanity: Disgust, Shame, and the Law, Princeton University Press, 2004; Frontiers of Justice: Disability, Nationality, Species Membership, Harvard University Press, 2006; The Clash Within: Democracy, Religious Violence, and India's Future, 2007; Liberty of Conscience: In Defense of American's Tradition of Religious Equality, New York: Basic Books, 2008; From Disgust to Humanity: Sexual Orientation and Constitutional Law, Oxford University Press, 2010; Not for Profit: Why Democracy Needs the Humanities, Princeton University Press, 2010

83 E. Jackson, N. Lacey, op. cit., p.788. 


\section{FEMINIST LEGAL THEORY: OUTLINE OF THE ISSUE}

In theory and philosophy of law, or as one can say, in jurisprudence, the dispute about the nature of the law has existed for ages. Traditionally, the axis of the dispute was denoted by advocates of natural law and legal positivism. One of the challenges to traditional conceptions of law is the Feminist Legal Theory.

Probably, gender will be an important axis of social division. However, we must agree that it will be not only, or even necessarily, the most substantial factor. There are many elements of structural social differentiation.

Although the direction of feminist legal theories development is not determined and most non-feminist legal theories adopt either an internal or an external critique, feminist legal theories try to occupy a third perspective: the interpretative one. It means that feminism does not engage in entirely external critiques and prescriptions; it typically does not seek to rationalize legal practices. Feminist jurisprudence aspire to produce an account of legal practices which have a particularly intimate relevance to theory. Any clear-cut separation between theory and practices is rejected.

Key words: sex, feminism, jurisprudence, theories, philosophy 


\section{FEMINISTYCZNA TEORIA PRAWA}

W teorii i filozofii prawa, lub jako można powiedzieć, w jurysprudencji, spór o naturę prawa toczy się od wieków. Tradycyjnie jego oś sporu wyznaczali zwolennicy prawa naturalnego i pozytywizmu prawniczego. Jednym z wyzwań dla tradycyjnych koncepcji prawa jest feministyczna teoria prawa.

Prawdopodobnie płeć stanie się ważną osią społecznego podziału lub także jego najbardziej istotnym czynnikiem. Choć oprócz niej istnieje wiele elementów strukturalnego zróżnicowania społecznego.

Chociaż kierunek rozwoju feministyczna teorii prawnych nie został dotąd określony a większość nie-feministycznych teorii prawnych polega na prowadzeniu wewnętrznej lub zewnętrznej krytyki, to te pierwsze zakładają przyjęcie innej postawy: interpretacyjnej. Oznacza to, że feminizm nie angażuje się w całkowicie zewnętrzne krytyki; zazwyczaj nie usiłuje racjonalizować praktyk prawnych. Feministyczna jurysprudencja aspiruje do prezentacji zestawu praktyk o wyjątkowo bliskim związku z teorią. Wszelkie wyraźne oddzielenie teorii i praktyki jest odrzucane. 